\title{
CUSTOMER RELATIONSHIP MANAGEMENT IN HOSPITALS
}

\author{
Bhuvaneswari Gowthaman', S.S.Rau ${ }^{2}$ \\ ${ }^{1}$ Research Scholar, ${ }^{2}$ Registrar, \\ ${ }^{1,2}$ Sathyabama University, Rajiv Gandhi Road, Chennai, India \\ Email: 'Bhuvana_jk20@yahoo.com
}

\begin{abstract}
The report aims at presenting some of the CRM concepts and elements and formulates CRM strategy to take proactive measures towards customer-centric business in hospitals and also to improve customer satisfaction by building up better customer relationships leading to increase in revenues. Taking care of Patients, their needs and making relationships with patients is a common and routine activity in hospitals, it is essential that CRM has to focus on the prospective healthy customers(other than patients) who visit the hospital and concern for their health check offered by the hospital for supporting their life and monitoring of heath. Now-a-days every individual has a great concern for his health and in anticipation of any health problems, if any, in future; he is able to face the financial crisis by purchasing appropriate health cards. This report focuses on the customer-centric health packages in hospitals, profile of customers, their behavior and finally determining the relationship factors to design CRM strategy.
\end{abstract}

Key words: Customer relationship Management, Patient satisfaction, Healthcare, information management

\section{INTRODUCTION}

As we enter the 21 st century, changes are apparent and indeed desirable in our attitudes and mindset. Old practices give way to new ones and hospital administrators in contemporary times are not untouched by all this. Slowly, but surely, the healthcare market is changing from being primarily a sellers' market to being a buyers' market. A beginning in this direction has been made in the developed countries by the now well evolved system of managed care. Grabbing a lion's share of the healthcare market in the future will be the aim of many a healthcare organization in India as well. Other than clinical excellence, healthcare providers now recognize the presence of other factors playing a role in the sharecapturing game. The realization of the need for marketing in hospitals has gained momentum in recent years. Rapidly changing developments in the healthcare field will see more emphasis being placed on marketing of hospital services. A hospital's success will depend more and more on strategic planning based on timely and accurate information

\section{Market Research and Market Information Systems in Healthcare}

Marketing activities are designed to create value in planning, organising, pricing and delivering healthcare services. Marketing is defined by Philip Kotler as "a social \& managerial process whereby individuals and groups obtain what they need and want through creating and exchanging products and value with others". Another definition of marketing by American Marketing Association is "process of planning \& executing the conception, pricing, promotion \& distribution of ideas, goods and services to create exchanges that satisfy individual and or organisational goals". Some of the key terms in the above definitions include Value, Satisfaction and Quality. Customer value is the difference between values the customer gains from owning and using a product and the costs of obtaining the product. A more important concept for us is customer satisfaction, which is the extent to which a products' perceived performance matches a buyers expectations. If perceived performance falls below the buyer's expectations, customer is dissatisfied, but if perceived performance matches customers' expectations, buyer is satisfied. However, if perceived product performance exceeds customer expectations, buyers are delighted. A need for developing a system to identify such expectations is therefore felt.

Market Information System is a continuing and interacting structure of people, equipment and procedures to gather, sort, analyse, evaluate and distribute needed, timely and accurate information to marketing decision makers. One part of MIS is Market Research, which implies systematic design, collection, analysis and reporting of data relevant to a specific marketing situation facing an organisation. This is equally relevant for hospital administrators, as timely, accurate and adequate information is a prerequisite for making marketing decisions regarding delivery of hospital services. One of the Market Research tools helpful in addressing this issue is a Patient Expectation Survey (PES). This could be an initial marketing activity of an upcoming hospital or could also be an ongoing process in response to a certain problem being faced by the hospital. A patient expectation survey may also be included in the hospital's Customer Relationship Management (CRM) activities.

\section{The Issue of Quality}

Another key term in marketing is Quality. Quality has various definitions, and in the narrowest sense means 
'freedom from defects'. However, American Society for Quality Control defines quality as 'totality of features and characteristics of a product or service that bear on its ability to satisfy customer needs.' Even 'six sigma'-the current highest level of achievable quality, is measured in terms of number of defects per million parts. But as far as the service industry is concerned, what is a defect? Some organisations believe that 'anything that does not satisfy the customer is a defect'. Patients nowadays are more aware and more quality conscious than before. So, it stands to reason that a high level of quality, which can translate into patient satisfaction and hence profitability is important for a hospital. A very good method for ensuring this would be a patient expectation survey.

\section{Expectancy-Disconfirmation Paradigm Model: the relation between expectation and satisfaction}

If patients are viewed as consumers, a consumer model such as Expectancy- Disconfirmation model from marketing theories (Fig. 1) can be applied to healthcare provision. In this model (Fig. 2), the assumption is that patients have expectations when they visit a hospital. These expectations arise from prior experience or wordof-mouth communication, third party information or cultural milieu. The degree to which these expectations are fulfilled can be measured and there is a relationship. The higher the perceived fulfillment of expectation is higher is the satisfaction. When fulfillment is lower than expectation, the lesser is the satisfaction. When expectations are low, they are easily fulfilled and satisfaction level is kept high and vice versa.

Disconfirmation of pre-consumption expectations is the key influence on consumer satisfaction.

- Positive disconfirmation: performances exceed expectations

- Negative disconfirmation: expectations are not met

\section{Ceiling floor effect:}

Very high expectations (ceiling) are more likely to result in negative disconfirmation and very low expectations (floor) in positive disconfirmation.

\section{The economics of patient satisfaction}

Consumer satisfaction is important to the marketer because it is generally assumed to be a significant determinant of repeat sales; positive word-of-mouth, and consumer loyalty. Worldwide studies have shown that patient satisfaction is a required outcome in a hospital. It has also been seen that consumer satisfaction increases profitability of organisations. Just a one percent increase in satisfaction can produce up to a three percent increase in market capitalization. It has also been found that it can cost three or four times as much to acquire a new customer than to make a repeat sales to an existing one. However, healthcare organisations were not spending much on marketing activities until recently. It was reported by Kotler in 1987 that most healthcare organisations spend less than one and one fourth percent of their budget in recognised marketing activities, compared to ten times that amount in many industries, and that this was predicted to change.

\section{EXPECTANCY-DISCONFIRMATION PARADIGM : MODEL OF CONSUMER BEHAVIOUR}

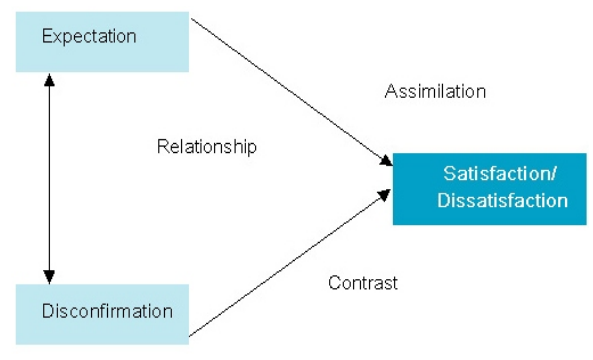

Fig. 1.

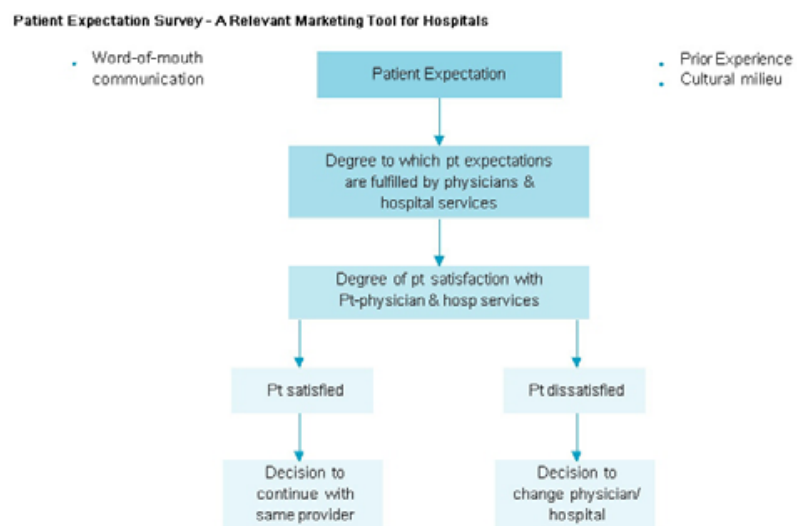

Source : Adapted from Baron-Epel, et al, Evaluation of the Consumer Model; relationship between patients expectation, perceptions and satisfaction with care, International Journal for Quality in Healthcare 2001; 13:317-323

Fig. 2.

Recently an increased interest in patient satisfaction studies has been observed due to an increased need for provision of quality healthcare and increasing competition among healthcare providers. Patient satisfaction is thus one of the desired outcomes of hospital care.

The need for patient expectation survey (referred herein as PES)

1. APES allows for need assessment of services in both qualitative and quantitative terms, leading to practice of sound evidence-based management practices.

2. Provisioning of quality services to consumers, which fulfils expectations and therefore has a higher chance of providing satisfaction to consumers. 
3. Health services being high on credence qualities, consumers rely more on friends' good prior experiences and reputation of a hospital for choosing a hospital than any other promotional measure. A PES therefore is a relevant marketing activity to ensure an optimum level of patient turnover by improving chances of patient satisfaction.

\section{Benefits of a PES}

1. Improved efficiency in marketing activities by rational and evidence-based management practices. This is expected to result in right health service offer at right price, right place, in the right milieu with right promotion and right feedback.

2. Cost-effective method of planning or reorganising services as compared to only patient satisfaction surveys, as PES is done prior to provisioning of services, therefore eliminating costs of experimentation.

3. Improved satisfaction of target markets, as services are now as per expectations of patients

4. Improved chances of attraction of marketing resources such as funds, human resource, public support and governmental support.

With the above background, the following study was conducted

Aim - To conduct a patient expectation survey among patients visiting the Outpatient department of two government hospitals.

\section{Study Setting and design}

A patient expectation survey was conducted among patients visiting the outpatient departments of two government hospitals in Chennai. The two hospitals were selected to give a wide base for conducting a survey. Outpatient Department of both hospitals was selected as setting of study as OPD is known as the shop window of a hospital, and has the maximum impact as far as repeat visits are concerned; a factor which is important to the marketer. In the context of resource crunch and rising costs, the OPD contributes to cost containment as well as revenues in a hospital, and thus is important to the hospital administrator. A total of 230 patients $(n=230)$ were surveyed.

This survey was carried out in two phases. In the first phase, a pilot study was done among 30 patients attending OPDs of different specialties, by conducting interviews with the help of a semi-structured questionnaire containing open-ended questions. Prior verbal consent was obtained from all participants in the survey. Undertaking was given that their identity will not be revealed in any form and information gathered in this interview will be used only for academic purposes. This pilot study revealed the general expectations among patients visiting hospitals. Based on the findings of the pilot study, a structured questionnaire was constructed and used to interview 100 patients each in the two hospitals. Every $5^{\text {th }}$ patient was interviewed to eliminate interviewer bias. This questionnaire contained both open and close-ended questions about what patients expected from hospitals and physicians, along with questions intended to elicit demographic and socioeconomic data of respondents. The questions asked in the second phase were based on findings of the pilot study as well as factors known in literature as service quality attributes (Parasuraman et al). Other than affirmative/negative answer question, rating scale questions were also asked. Some questions may appear to be rudimentary to the experienced, but nonetheless were asked in the interview considering that there may be expectations associated with situations in which some elements of service are so self-evident to customers, that they do not think about them, or about the possibility that these might not materialize (e.g physical examination by the physician). The existence of such expectations becomes obvious when these are not realized. These are known as implicit expectations. If such expectations are not met, these cause negative surprise, causing dissatisfaction, but when these are met, they do not bring a positive surprise 23 , akin to Hygiene factors in the Twofactor theory of motivation. In order to use the data thus obtained to chalk out a marketing strategy for the two hospitals, it was realized that it is not enough to study the patient expectation analysis in isolation. It will better serve its purpose when analysed in conjunction with a performance analysis of the hospital service under consideration. Therefore a expectation-performance analysis is needed to be made for all attributes, but especially so for the attributes which are relatively more important to the patients. Marketing/improvement strategies based on these parameters will be thus a sound evidence-based marketing strategy and not an empirically decided one. Therefore, questions regarding actual performance of these hospitals with respect to different attributes of services which were explored in patient expectation survey in these hospitals, were also asked from respondents.

\section{Observations:}

Observations of the data compiled are presented below in Table-1 \& Table 2 
Table 1. Demographic \& socio-economic data

\begin{tabular}{|c|c|c|c|}
\hline S.No & $\begin{array}{l}\text { Demograph } \\
\text { ic I Socio- } \\
\text { Economic } \\
\text { Factors }\end{array}$ & $\begin{array}{l}\text { Secondary } \\
\text { Care } \\
\text { Hospital }\end{array}$ & $\begin{array}{l}\text { Tertiary } \\
\text { Care } \\
\text { Hospital }\end{array}$ \\
\hline 1 & $\begin{array}{l}\text { Median age } \\
\text { of patients }\end{array}$ & 30.9 yrs & 32.3 yrs \\
\hline 2 & \multicolumn{3}{|l|}{ Gender } \\
\hline & Males & $63 \%$ & $66 \%$ \\
\hline & Females & $36 \%$ & $33 \%$ \\
\hline \multirow[t]{6}{*}{3} & \multicolumn{3}{|c|}{ Educational level } \\
\hline & $\begin{array}{l}\text { Post- } \\
\text { graduate }\end{array}$ & $5 \%$ & $14 \%$ \\
\hline & Graduate & $8 \%$ & $33 \%$ \\
\hline & $\begin{array}{l}\text { Trade } \\
\text { school }\end{array}$ & $9 \%$ & 0 \\
\hline & Matriculate & $26 \%$ & $40 \%$ \\
\hline & $\begin{array}{l}\text { Below } \\
\text { matriculation }\end{array}$ & $52 \%$ & $13 \%$ \\
\hline 4 & \multicolumn{3}{|l|}{ Profession } \\
\hline & Service & - & $60 \%$ \\
\hline & Business & - & $7 \%$ \\
\hline & $\begin{array}{l}\text { Self- } \\
\text { employed }\end{array}$ & - & $27 \%$ \\
\hline & $\begin{array}{l}\text { Factory } \\
\text { worker }\end{array}$ & $100 \%$ & 0 \\
\hline & Unemployed & - & $6 \%$ \\
\hline 5 & \multicolumn{3}{|c|}{ Coverage by health insurance } \\
\hline & Mediclaim & - & 0 \\
\hline & $\begin{array}{l}\text { ESIC/CGHS } \\
\text { /Railways/ot } \\
\text { hers }\end{array}$ & $100 \%$ & $20 \%$ \\
\hline & $\begin{array}{l}\text { Employer } \\
\text { based } \\
\text { reimbursem } \\
\text { ent }\end{array}$ & - & $20 \%$ \\
\hline & $\begin{array}{l}\text { No } \\
\text { insurance, } \\
\text { out-of- } \\
\text { pocket } \\
\text { payments } \\
\text { only }\end{array}$ & - & $60 \%$ \\
\hline
\end{tabular}

Table 2. Comparison of Expectation \& performance levels in Secondary Hospital \& Tertiary Hospital

\begin{tabular}{|c|c|c|c|c|c|}
\hline \multirow[t]{2}{*}{$\begin{array}{l}\text { S. } \\
\text { No }\end{array}$} & \multirow{2}{*}{$\begin{array}{l}\text { Attributes } \\
\text { of Service } \\
\text { by } \\
\text { Hospital/P } \\
\text { hysician }\end{array}$} & \multicolumn{2}{|c|}{$\begin{array}{l}\text { Expectations ( } \% \text { of } \\
\text { respondents) }\end{array}$} & \multicolumn{2}{|c|}{$\begin{array}{l}\text { Actual } \\
\text { Performance(\% o } \\
\text { respondents) }\end{array}$} \\
\hline & & $\begin{array}{l}\text { Second } \\
\text { ary } \\
\text { Hospita } \\
\text { I }\end{array}$ & $\begin{array}{l}\text { Tertiary } \\
\text { Hospital }\end{array}$ & $\begin{array}{l}\text { Second } \\
\text { ary } \\
\text { Hospita } \\
\text { I }\end{array}$ & $\begin{array}{l}\text { Tertiary } \\
\text { Hospital }\end{array}$ \\
\hline \multirow{7}{*}{1} & \multicolumn{5}{|c|}{ Waiting time in doctors queue } \\
\hline & $-5-10 \mathrm{~min}$ & 0 & 0 & 0 & 0 \\
\hline & $-10-20 \mathrm{~min}$ & $21 \%$ & $29 \%$ & 0 & 0 \\
\hline & $-20-30 \mathrm{~min}$ & $26 \%$ & $40 \%$ & $11 \%$ & $4 \%$ \\
\hline & $\begin{array}{l}-30 \min -45 \\
\min \end{array}$ & $53 \%$ & $31 \%$ & $21 \%$ & $4 \%$ \\
\hline & $->1 \mathrm{hr}$ & 0 & 0 & $47 \%$ & $72 \%$ \\
\hline & $->2 \mathrm{hr}$ & 0 & 0 & $21 \%$ & $20 \%$ \\
\hline \multirow{5}{*}{2} & \multicolumn{5}{|c|}{ Consultation time by doctors } \\
\hline & $-5 \mathrm{~min}$ & $32 \%$ & $7 \%$ & $78 \%$ & $67 \%$ \\
\hline & $-5-10 \min$ & $42 \%$ & $53 \%$ & $16 \%$ & $13 \%$ \\
\hline & $-10-15 \min$ & $15 \%$ & $20 \%$ & $6 \%$ & 0 \\
\hline & $-15-20 \mathrm{~min}$ & $11 \%$ & $20 \%$ & 0 & $13 \%$ \\
\hline \multirow{4}{*}{3} & \multicolumn{5}{|c|}{ Expect doctors to listen to problems? } \\
\hline & -Yes & $100 \%$ & $100 \%$ & $63 \%$ & $73 \%$ \\
\hline & - No & 0 & 0 & $16 \%$ & $7 \%$ \\
\hline & $\begin{array}{l}\text { Sometime } \\
\mathrm{s}\end{array}$ & 0 & 0 & $21 \%$ & $20 \%$ \\
\hline \multirow{4}{*}{4} & \multicolumn{3}{|c|}{$\begin{array}{l}\text { Expect doctors to answer } \\
\text { patients? }\end{array}$} & \multicolumn{2}{|c|}{ questions put by } \\
\hline & - Yes & $100 \%$ & $100 \%$ & $53 \%$ & $60 \%$ \\
\hline & - No & 0 & 0 & $47 \%$ & $13 \%$ \\
\hline & $\begin{array}{l}\text { Sometime } \\
\mathrm{s}\end{array}$ & & & & $27 \%$ \\
\hline \multirow{4}{*}{5} & \multicolumn{5}{|c|}{ Physical examination by physician } \\
\hline & - Yes & $100 \%$ & $100 \%$ & $58 \%$ & $87 \%$ \\
\hline & - No & 0 & 0 & $32 \%$ & $13 \%$ \\
\hline & $\begin{array}{l}\text { Sometime } \\
\mathrm{s}\end{array}$ & 0 & 0 & $10 \%$ & 0 \\
\hline \multirow{3}{*}{6} & \multicolumn{5}{|c|}{ Discussion of problem with pt } \\
\hline & - Yes & $79 \%$ & $80 \%$ & $32 \%$ & $80 \%$ \\
\hline & -No & $21 \%$ & $20 \%$ & $68 \%$ & $20 \%$ \\
\hline
\end{tabular}




\begin{tabular}{|c|c|c|c|c|c|}
\hline \multirow{3}{*}{7} & \multicolumn{5}{|c|}{ Health education \& dietary counseling by doctors } \\
\hline & -Yes & $79 \%$ & $80 \%$ & $63 \%$ & $20 \%$ \\
\hline & - No & $21 \%$ & $20 \%$ & $37 \%$ & $80 \%$ \\
\hline \multirow{4}{*}{8} & \multicolumn{5}{|c|}{ Reference for investigations } \\
\hline & -Yes & $84 \%$ & $100 \%$ & $21 \%$ & $100 \%$ \\
\hline & -No & $16 \%$ & 0 & $26 \%$ & 0 \\
\hline & $\begin{array}{l}\text {-Not every } \\
\text { time }\end{array}$ & & & $53 \%$ & 0 \\
\hline \multirow{4}{*}{9} & \multicolumn{5}{|c|}{ Attitude/behavior of doctors (empathy) } \\
\hline & \begin{tabular}{|l|} 
Polite \& \\
personal
\end{tabular} & $78 \%$ & $100 \%$ & $36 \%$ & $100 \%$ \\
\hline & $\begin{array}{l}\text {-Attitude } \\
\text { doesn't } \\
\text { matter }\end{array}$ & $21 \%$ & 0 & 0 & 0 \\
\hline & \begin{tabular}{|l|}
-Rude \& \\
uncaring
\end{tabular} & 0 & 0 & $64 \%$ & 0 \\
\hline \multirow{5}{*}{10} & \multicolumn{5}{|c|}{ Privacy in doctors chambers } \\
\hline & $\begin{array}{lll}\text {-Just } & \text { dr } & \& \\
\text { pt } & & \end{array}$ & $63 \%$ & $47 \%$ & $16 \%$ & $51 \%$ \\
\hline & $\begin{array}{l}\text {-Dr, pt \& } \\
\text { nurse }\end{array}$ & $16 \%$ & $27 \%$ & $11 \%$ & 0 \\
\hline & \begin{tabular}{|lr} 
Dr, & pt, \\
nurse $\quad$ \& \\
other & \\
patients &
\end{tabular} & $5 \%$ & 0 & $73 \%$ & $49 \%$ \\
\hline & \begin{tabular}{|l|}
-Makes no \\
difference
\end{tabular} & $16 \%$ & $26 \%$ & & \\
\hline
\end{tabular}

\begin{tabular}{|c|c|c|c|c|c|}
\hline & Expectatior & abou & hysic & ilities & \\
\hline & \begin{tabular}{|l|}
-Standing \\
space with \\
drinking \\
water \& \\
toilets
\end{tabular} & $16 \%$ & $0 \%$ & $71 \%$ & $9 \%$ \\
\hline 11 & \begin{tabular}{|l}
-Sufficient \\
seating \\
arrangeme \\
nts, with \\
drinking \\
water \& \\
toilets, \\
high \\
sanitation \\
level
\end{tabular} & $73 \%$ & $93 \%$ & $29 \%$ & $91 \%$ \\
\hline & \begin{tabular}{|l}
-Maybe \\
anything, \\
its not \\
important
\end{tabular} & $11 \%$ & $7 \%$ & & \\
\hline
\end{tabular}

\section{Analysis and Discussion}

There are both similarities and differences in the expectations of patients visiting both the hospitals as well as performance of the hospital. This is observed despite the fact that one hospital is a secondary level care hospital catering to a select clientele, and the other one is a tertiary level care government referral hospital.

\section{Demographic and socio-economic factors}

Among the demographic and socio-economic factors, similarity was observed in median ages of respondents in both hospitals, more males were observed visiting hospitals than females in both situations and insurance coverage of some kind was observed in both hospitals although there was a wide variation in these percentages. The most notable difference was in the literacy levels of the patient groups of the two hospitals. In the secondary hospital, $48 \%$ of respondents were matriculate or above, whereas in the tertiary hospital, $87 \%$ were matriculate and above. $60 \%$ of the respondents were noted to be in service and $27 \%$ were self-employed in tertiary hospital as against all salaried workers in secondary Hospital. Only $40 \%$ respondents in tertiary hospital had some kind of insurance/reimbursement coverage and $60 \%$ were paying out-of pocket. This then, points to a major difference in the cultural and socio-economic milieu of the patient groups of the two hospitals.

Analysis of medical care attributes: Expectations visà-vis Performance perceptions

\section{Waiting Time}

Majority of patients in Secondary Hospital expected waiting time to be $30 \mathrm{~min}$ to $45 \mathrm{~min}(53 \%)$ as against 20-30 min by (40\%) in the tertiary hospital. The performance shows that majority of patients in both hospitals; i.e $72 \%$ in tertiary hospital and $47 \%$ in secondary hospital had to wait for more than $1 \mathrm{hr}$ for their turn.

\section{Implication}

Expectations are higher from Tertiary Hospital than secondary hospital, possibly due to the difference in socio-economic \& cultural milieu of the two patient groups.

- Scope of dissatisfaction is higher in Tertiary Hospital due to lower performance levels

- Marketing strategy- Tertiary Hospital as well as secondary hospital need to augment services and streamline the number of patients seen per physician, so as to decrease waiting time and improve patient satisfaction, as a decrease in number of patients is not be expected/possible. 


\section{Consultation Time}

In the tertiary hospital, $54 \%$ respondents expected Consultation Time to be 5-10 min and $40 \%$ expected 1020 min, whereas in secondary hospital, only $42 \%$ expected 5-10 min Consultation Time, whereas 32\% expected this to be less than $5 \mathrm{~min}$. As far as performance is concerned, majority of patients in both hospitals got less than 5 min as consultation time.

\section{Implication}

\section{- Expectation higher from Tertiary Hospital}

- Tertiary Hospital as well as Secondary hospital needs to improve consultation time duration by augmentation of services.

This study reveals that at present with the current number of consultants waiting time is more and consultation time less as compared to expectation of people. Expectations are higher from tertiary hospitals. Both hospitals need to augment services so as to meet expectations of their clientele.

\section{Listen to problems \& answer questions}

$100 \%$ patients in both hospitals expect physicians to listen to their problems and answer their queries, as against $73 \%$ \& $63 \%$ in Tertiary and Secondary Hospital who were listened to respectively and $60 \%$ and $52 \%$ patients who were answered to respectively in the Tertiary and Secondary Hospital

\section{Implications}

- Potential dissatisfaction causing factor

\section{- Sensitize doctors about above in both hospitals}

Here again in both hospitals, expectations were not met and this needs attention. There is need to sensitize doctors about patient expectations, which if heeded to, can improve the situation without any additional input in terms of resources

\section{Physical examination by physician}

$100 \%$ patients in both hospitals expected to be physically examined. But only $53 \%$ pts in the secondary hospital and $87 \%$ in the tertiary hospital reported that a physical examination was done. Physicians might argue here that a physical examination is not necessary in every visit and this may very well be true. But this fact needs to be communicated to the patient who is expecting it nonetheless, and this will set his/her mind at rest.

\section{Implications}

Fulfillment of patient expectations in this regard in Secondary Hospital needs focus. This can easily be done by communicating these expectations to doctors.

\section{Discussion of problem with patient and explanation of treatment}

About $80 \%$ pts in both hospitals expected the physicians to discuss their problems with them. But this expectation was reported to be met by $32 \%$ patients in Secondary Hospital and $80 \%$ pts in Tertiary Hospital. Physicians of Tertiary Hospital thus scored higher than doctors in Secondary Hospital in this communication aspect.

\section{Implications}

Doctors in Secondary Hospital may be sensitized about this aspect for achieving a higher level of patient satisfaction.

\section{Health education \& dietary counseling by doctors}

A factor peculiar to the Indian mindset was chanced upon during the $1^{\text {st }}$ phase of the study. This was the expectation of patients related to dietary advice. This particular factor was seen to be so well ingrained in the Indian psyche, that respondents to the extent of $80 \%$ in both the hospitals, despite the vast difference in their socio-economic and cultural milieu, expected their physicians to give them specific dietary advice and health education. In complete contrast to the previous findings on communication aspects, doctors of the Secondary Hospital scored $63 \%$ in the performance analysis as against only $20 \%$ doctors in the Tertiary Hospital fulfilling expectations of patients in this regard. This may possibly be explained by the fact that physicians in Tertiary Hospital give more specialty related advice rather than general dietary advice, and leave this to be done by dieticians, as mentioned by some respondents in the $2^{\text {nd }}$ phase of study. Physicians in Secondary Hospital being generalists, possibly give more general dietary advice.

\section{Implications}

Expectations of patients regarding diet needs to be communicated to the doctors, as to how important it may be to patients and how it can positively effect patients' psyche, resulting in higher satisfaction and better compliance to advise of doctor.

\section{Reference for investigations}

It was seen that $84 \%$ patients in the Secondary Hospital and all the patients in the Tertiary Hospital expected to be referred for investigations, but only $21 \%$ patients in 
Secondary Hospital were referred for investigations as against all the patients in Tertiary Hospital who were referred for investigations. This may possibly be explained by the type of patients visiting the Tertiary Hospitalprobably being complicated cases requiring a lot of investigations.

\section{Implications}

Nowadays, modern medicine is increasingly relying upon investigations and public have come to judge services by investigations asked for. Here doctors cannot be expected to order investigations just as patients expect, rather this information can be communicated to the doctor who in turn, can explain to patients why investigations are/not required. This will allay the anxiety of patients and result in better compliance with advice and result in improved satisfaction.

\section{Attitude/behavior of doctors (empathy)}

$78 \%$ respondents in Secondary Hospital expected their physician to be polite, as against $100 \%$ in the Tertiary Hospital. This expectation was fulfilled completely in case of the Tertiary Hospital, but fell far short in the Secondary Hospital where only $36 \%$ of respondents found their expectations fulfilled in this regard.

\section{Implications}

- Patients expect doctors to be polite and with improved socio-economic status, this expectation becomes more explicit. If doctors are not perceived to be polite this can be a significant dissatisfier. Doctors in secondary hospital need to be counseled and sensitized on this account.

- With proper feedback, there is tremendous scope of improvement in the Secondary Hospital.

\section{Expectation from Physical Facilities (tangibles)}

As regards the physical facilities, the majority of respondents in both hospitals, i.e $73 \%$ in Secondary Hospital and $93 \%$ in Tertiary Hospital expected to have sufficient seating arrangements, drinking water and toilets along with high sanitation levels. But the physical facilities were found adequate by only $29 \%$ of respondents in the Secondary Hospital as against $91 \%$ by those visiting Tertiary Hospital. Physical facilities are seemingly adequate in the Tertiary Hospital, but there is a wide scope for improvement in Secondary Hospital.

\section{Implications}

- Nowadays public is highly discerning and they expect hospitals to provide clean and hygienic environment with adequate civic amenities. As our hospitals at times, lack these, public goes back dissatisfied. Hospitals need to take regular measures to upgrade facilities and match expectations.

- Expectation higher from Tertiary Hospital than from Secondary Hospital as far as tangibles are concerned.

- Secondary Hospital needs to improve physical facilities and amenities.

\section{Expectations from Doctors regarding clinical competence (reliability/assurance)}

Respondents were quizzed about their expectation about a doctor's degrees/qualification vis-à-vis their competence. $47 \%$ respondents in Secondary Hospital expected their physician to be a specialist, whereas $42 \%$ respondents said they were unable to judge a physician's clinical competence. In case of the Tertiary Hospital, $66 \%$ expected their physicians to be a specialist while $21 \%$ said they were unable to judge a physician's clinical competence.

\section{Implications}

- More and more people are demanding specialist care. Thus secondary hospitals need to have specialists in adequate number as this has a bearing on perception of the patient regarding competence of the doctor, which influences his/her overall assessment of the hospital.

- As a strategy, administration may display the physician's names along with their qualifications. This will have a positive impact on the perception of the patient regarding clinical competence of the doctor.

11. Rating of various attributes in the order of importance as deemed by the patients.

Respondents were asked to rate the various attributes of hospital services in the order of relative importance as judged by them, with the most important rated as 1 and least important rated as 5 . It was seen that both groups of respondents rated a 'good doctor' as the most important attribute. Implicit in the term 'good doctor' is one who examines them, listens to their problems, answers their questions, is empathetic, polite, offers specific advice and one who is able to cure them (technically competent). In the Secondary Hospital the number two rating was given to physical facilities and sanitation, probably due to the perception that this was lacking in the Secondary Hospital (refer to point number 10 above). However, the attitude of the physicians was more important to clientele in the 
Tertiary Hospital (rated $2^{\text {nd }}$ ) than physical facilities and sanitation (rated $5^{\text {th }}$ ). This could probably be explained due to the higher levels of literacy and awareness and sensitivity to this issue, and the perception of good physical facilities and high sanitation levels by a large majority of respondents. Treatment and investigations were rated almost similarly by both groups at numbers 3 and 4 .

\section{Implications}

- Patients in both hospitals consider good doctor with the 'ability to cure' as the most important attribute of medical care in a hospital. Different attributes which matter most to patients are almost same, but relative importance of these is a function of background (socio-economic status) and what is available in the hospital. But the most important thing is the doctor, who should be not only be competent i.e able to treat, but also have good communication skills and is empathetic. Good environment is needed to create a right impression on the patient, and absence of the same can have a negative impact.

- Marketing strategy- without technically or clinically competent doctors, a high level of patient satisfaction is difficult to achieve.

- Physical facilities and sanitation rate high in patient expectations implicitly.

\section{Discussion}

Expectations vary from hospital to hospital and from one socio-economic stratum to another. Both similarities and differences are seen in the expectations of patients frequenting both hospitals. Despite the obvious difference in socio-economic strata of the target markets of the two hospitals and the difference in the stature of the two hospitals themselves, one feature stands out prominently. This is the consideration of technical competencies of the physicians or the 'ability to cure', communication skills and empathetic attitude, as the most important attribute of medical care in a hospital, by patients in both hospitals. Therefore, any marketing strategy devised in this regard must keep in view that without right doctors (right doctortechnically competent, with sound communication skills and empathetic attitude), a high level of patient satisfaction is difficult to achieve. It is well known that some service components will have greater influence on consumers' assessment of the overall service than others. In context of medical care, the care provided by the physician probably has a strong influence on overall assessment and resultant satisfaction with care provided. This can actually be the USP in a marketing strategy of hospitals.

In general, patients have a higher expectation from the Tertiary Hospital than secondary hospital. This may possibly be explained by a higher incidence of literacy level in patients visiting the Tertiary Hospital. Increased literacy levels generally lead to an increased demand for quality healthcare, which in this case is possibly expressed by a higher level of explicit expectations.

In particular, in both hospitals, waiting time in physicians' queues and duration of consultation time appear to be potentially dissatisfaction causing factors. Hospital administrators of both hospitals need to devise strategies to mitigate the affect of these factors. Both hospitals also need to have a strategy of improving communication skills of physicians.

Since both hospitals appear to be patronized by a particular target market, hospital administrators can devise a marketing strategy based on expectations of patients as determined by a PES. Since there could possibly be a large number of expectations, along with expectation-performance variation instances, it would be impractical for a hospital marketing manager to devise solutions for all of those. Hence, he/she will need to prioritize issues based on particular constraints facing the hospital. As a recommendation, administrators of Secondary Hospital should devise strategies keeping in mind the importance given to communication skills of doctors, physical facilities and investigations by the patients. Tertiary hospital administrators may concentrate on strategies on lessening waiting time and increasing consultation time.

\section{Conclusion}

Patient expectation survey can be considered as a pro-active marketing activity designed to have a better chance at achieving patient satisfaction. Research in expectation-performance analysis has been conducted in areas of marketing such as health care to chalk out marketing strategies. Sufficient information has been elicited regarding expectations of patients from hospital services in general and outpatient department in particular. It is seen that if any hospital fulfils expectations of patients, patients are more likely to stay with that particular service provider for a longer time. Patient satisfactions is also the desired outcome of any hospital. Therefore it would be beneficial to use a patient expectation survey to plan outpatient services and sensitize physicians about expectations of patients, to ensure a higher chance of patient satisfaction. Such an approach has also been found to be a cost-effective method for reaching large markets. This would be a desirable step in marketing the hospital as a responsive organization. Patient expectation surveys will lead to a evidence-based and rational use of scarce resources However, it would be best to use such a patient expectation survey in conjunction with a patient 
satisfaction survey to complete the 'before' and 'after' picture. It can reasonably be concluded that in the current competitive healthcare scenario, patient satisfaction surveys in respect of a particular service can be an important market information and research tool in the hands of contemporary hospital administrators.

\section{REFERENCES}

1. Schoenfeldt RC, Seale WB, Hale AW " Survey Alerts Hospital to Needs of Consumers" Health Prog. 1987 Sep;68(7):61-6

2. Kotler Philip, Armstrong Gary, Principles of Marketing, 9 th edition, 2001, Prentice-Hall of India pp 6-11

3. Kotler Philip, Clarke Roberta N, Marketing for Health Care Organization, Prentice-Hall, New Jersey, 1987, pp 162-168

4. Baron-Epel O, Dushenat M, Freidman N, Evaluation of the Consumer Model; relationship between patients expectation, perceptions and satisfaction with care, International Journal for Quality in Healthcare 2001;13:317-323

5. Thompson DA, Yarnold PR, Relating Patient Satisfaction to Waiting Time Perceptions and Expectations: The Disconfirmation Paradigm , Acad Emerg Med. 1995 Dec;2(12):1057-62

6. Donabedian A. The Quality of Care: How can it be assessed? JAm Med Assoc 1988:260; 1743-1748

7. Friar B, High Tech the old fashioned way, Harvard Business Review, March 2001.

8. Kotler Philip, Armstrong Gary, Principles of Marketing, 9 th edition, 2001, Prentice-Hall of India pp 667.

9. Lindel-Pelz S. Towards a Theory of Patient Satisfaction Soc Sci Medi 1982;16:577-582

10. Like R, Zyzanski SJ. Patient Satisfaction with Clinical Encounter: Social Psychological Determinants Soc Sci Med 1987; 24: 351-357

11. Imanaka $Y$, Nobutomo $K$, Tokunaga J Effects of Patients Demands on Satisfaction with Japanese Hospital Care, International Journal for Quality in Healthcare 2000;12:395-401

12. Baron-Epel O, Dushenat M, Freidman N, Evaluation of the Consumer Model; Relationship Between Patients Expectation, Perceptions and Satisfaction with Care, International Journal for Quality in Healthcare 2001;13:317-323

13. Byer S. Patient-Based Surveying: A Cost-Effective Approach for Reaching Large Markets. Manag Care Q. 1995 Autumn;3(4):66-9.
14. Qidwai W, Dhanani RH, Khan FM. Implications for the Practice of a Patient Expectation And Satisfaction Survey, at a Teaching Hospital in Karachi, Pakistan. J Pak Med Assoc. 2003 Mar;53(3):122-5.

15. Zemencuk JK, Hayward RA, Skarupski KA, Katz SJ. Patients' Desires and Expectations for Medical Care: A Challenge to Improving Patient Satisfaction Am J Med Qual. 1999 Jan-Feb;14(1):21-7

16. Perron NJ, Secretan F, Vannotti M, Pecoud A, Favrat B. Patient Expectations at a Multicultural Out-Patient Clinic in Switzerland. Fam Pract. 2003 Aug;20(4):428-33.(abstract)

17. Krohn Franklin B, Zboch Tina M, The Dilemma of Conflicting Attitudes: Survey Results or Community Perceptions? Journal of Hospital Marketing 1999 Vol 13(2): 5-22

18. Parasuraman, A, Zeithaml, V A \& Berry, L L (1988) "SEVQUAL: A Multi-Item Scale for Measuring Consumer Perceptions of Service Quality", Journal of Retailing, 64(1), Summer, p.12-40

19. Prakash, V (1984) "Validity And Reliability of the Confirmation of Expectations Paradigm as a Determinant of Customer Satisfaction", Journal of The Academy of Marketing Science, 12(4), Fall, p.63-76

20. Oliver, R L (1980) "A Cognitive Model of the Antecedents and Consequences of Satisfaction Decisions", Journal of Marketing Research, November 1980, p.460-468

21. Patrick Michelle $L$ et al, "Keeping the Medical Practice Financially Viable: A Marketers Approach" Health Marketing Quarterly, Vol19(4)2002,39-5

22. Hawes, John M. and C. P. Rao (1985), "Using Importance-Performance Analysis to Develop Health Care Marketing Strategies," Journal of Health Care Marketing, (Fall), 19-25.

23. Ojasalo Jukka, "Customer Expertise: A Challenge in Managing Customer Relationships in Professional Business-to-Business Services" Services Marketing Quarterly Vol22(2)2001;1-16

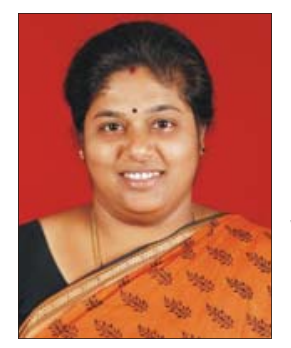

Bhuvaneswari. G

Research Scholar Sathyabama University. She has 9 years of Academic experience. She has organized several workshops and has presented several papers in national and international conferences. Her areas of research interest are Customer Relationship Managementand Service Marketing. 